VIRTUOUS VICE 
Edited by Michèle Aina Barale, Jonathan Goldberg, Michael Moon, and Eve Kosofsky Sedgwick 


\section{Virtuous Vice}

Homoeroticism and the Public Sphere

ERIC O. CLARKE

Duke University Press Durham and London, 2000 
(c) 2000 Duke University Press

All rights reserved

Printed in the United States of America on acid-free paper @

Typeset in Quadrat by Tseng Information Systems, Inc.

Library of Congress Cataloging-in-Publication Data

appear on the last printed page of this book. 
To my mother, Gerry Clarke, with love 
